\section{Investigating the Offending Histories of Undocumented Immigrants}

\author{
Bianca E. Bersani \\ Adam D. Fine \\ Alex R. Piquero \\ Laurence Steinberg \\ Paul J. Frick \\ Elizabeth Cauffman ${ }^{ \pm}$
}

\begin{abstract}
This study investigates the association between undocumented immigration and crime among youthful offenders. Using official record and self-reported offending measures collected across seven-waves of data from the longitudinal Crossroads Study, the prevalence and variety of offending are compared for undocumented immigrant, documented immigrant, and US-born groups during the transition into young adulthood. Results suggest that, as compared to documented immigrants and US-born peers, undocumented immigrants report engaging in less crime prior to and following their first arrest. Conversely, official records reflect a marginally higher level of re-arrest among undocumented immigrants, particularly in the months immediately following the first arrest. This divergence in findings warrants focused consideration to disentangle whether the difference is due to differential involvement in crime, differential treatment in the justice system, or a combination of factors. Additional research is needed to test whether the results found in this study generalize to other immigrant groups and contexts.
\end{abstract}

Keywords: undocumented immigrants; immigrants; offending; arrest; immigration-crime nexus.

\title{
Introduction
}

A quarter of the estimated 43.6 million immigrants who currently reside in the United States are unauthorised, and of the undocumented population, over half are Mexican (Passel \& Cohn, 2016). Concerns about the immigrant population, particularly those who are unauthorised, vary widely from job competition and

\footnotetext{
${ }^{ \pm}$Bianca E. Bersani, PhD, Department of Sociology, University of Massachusetts Boston, United States. Email: Bianca.bersani@umb.edu

Adam D. Fine, MA, Department of Psychology \& Social Behavior, University of California, Irvine, United States. E-mail: finea@uci.edu

Alex R. Piquero, PhD, Program in Criminology, University of Texas at Dallas, United States. E-mail: apiquero@utdallas.edu

Laurence Steinberg, PhD, Department of Psychology, Temple University, United States and King Abdulaziz University, KSA. E-mail: lds@temple.edu

Paul J. Frick, PhD, Department of Psychology, Louisiana State University, United States and Learning Science Institute of Australia, Australian Catholic University, Australia. E-mail: pfrick@1su.edu Elizabeth Cauffman, PhD, Department of Psychology \& Social Behavior, University of California, Irvine, United States. E-mail: cauffman@uci.edu.

Acknowledgement: This research was supported by the John D. and Catherine T. MacArthur Foundation and the Office of Juvenile Justice and Delinquency Prevention, and the County of Orange.
} 


\section{Offending Histories of Undocumented Immigrants}

healthcare costs to criminal proclivities (Chavez 2008; Wang 2012). The anxiety surrounding the 'criminal immigrant' resonates deeply despite a long history of empirical evidence showing that the foreign-born are less involved in crime than their US-born peers (Lee \& Martinez 2009). In a clear contrast to extant research, concerns voiced by immigration opponents to justify increasingly punitive measures and exclusionary policies underscore the crime that flows across the border owing to waves of immigration (Ewing, Martínez \& Rumbaut 2015).

The persistence of the perception that immigrants are crime prone may be due, in part, to the lack of studies distinguishing undocumented immigrants from their documented immigrant peers. Consequently, the low levels of crime observed among the foreign-born may mask the crime committed by a subgroup of immigrants with unauthorized residence in the US. Undocumented immigrants comprise a heterogeneous group and include those who entered the country illegally and those whose legal residency expired or was revoked. A nascent body of scholarship accounts for variation in immigrant status ${ }^{1}$ and is limited to correctional population samples (Hagan \& Palloni 1999; Hickman \& Suttorp 2008) or a focus on drug use (Katz et al., 2011). As a result, important questions remain concerning the prevalence and pattern of offending among undocumented immigrants, which hold import for current and emergent policies aimed at immigration reform and the enforcement of immigration laws.

This research fills an important void in the literature by examining the offending patterns of immigrant youth distinguished by their legal residency in the US. Using data from the Crossroads Study, a longitudinal investigation of male, first-time juvenile arrestees followed for three years, we examine the prevalence and variety of criminal behavior using official and self-reports of offending. The longitudinal nature of the data allow for the study of offending patterns during the precarious developmental period spanning adolescence into young adulthood (Monahan et al., 2015), when criminal involvement is at its peak (Hirschi \& Gottfredson 1983; Piquero et al. 2003). This may be an especially risky period for undocumented immigrants who, during the transition to adulthood, confront abruptly an illegal identity (Gonzales 2016). Our focus is on Latino immigrants, particularly Mexican immigrants, to the United States for two reasons: Latinos characterize the vast majority of immigrants to the US (Passel \& Cohn 2016), and in terms of policy, they represent a group of

\footnotetext{
${ }^{1}$ Variation in immigrant legal status has been measured and categorized in different ways. It is important to note that there is an increasing fluidity in the categories used to capture variation in status. Take, for instance, the criteria for those designated as removable or deportable that includes those who are undocumented as well as permanent legal residents, and in some cases, naturalized citizens, and potentially those with provisional executive residency authority. In this research, we distinguish undocumented from documented immigrants.
} 
immigrants who have long been branded as being at particular risk for detrimental outcomes, including crime, due to their persistent deficits and disadvantages (Hagan \& Palloni 1999; Portes \& Rumbaut 2006; Telles \& Ortiz 2008).

\section{Immigration and Crime}

Anxiety regarding the potential criminal proclivities of immigrants is longstanding and dates back, at least, to the turn of the $20^{\text {th }}$ century (see Simes \& Waters 2014). The extensive research on the immigrant-crime nexus yields little empirical evidence that immigrants are more crime-prone than US-born Americans (Lee \& Martinez 2009). The finding that the foreign-born are relatively less criminal holds in studies examining self-reported crime and risky behavior in general population studies (Bersani 2014; Bui 2009; Butcher \& Piehl 1998; Harris 1999; Vaughn et al. 2014), self-reported and officially recorded crime in offender based samples (Bersani et al. 2014; Jennings et al. 2013), and rates of recidivism and incarceration (Ibanez et al. 2016; Rumbaut et al. 2006). The lower levels of offending are not attributable to a differential tendency for the foreign-born to under-report their involvement in crime (see Bersani and Piquero 2017). The finding that immigrants have relatively low levels of criminal involvement, despite exposure to traditional criminogenic risks, is referred to as the immigrant paradox.

\section{Legal versus illegal immigration}

Illegal immigration and crime are inextricably linked; illegal entry is itself classified as a federal offense. Undocumented residency includes not only those lacking authorized entry to the US, but also individuals whose authorized entry and residency in the US has been revoked or expired. Historically, violations of immigration law were handled as administrative offenses, and the focus was directed at detaining and deporting individuals deemed serious or violent offenders (Meissner et al. 2013). Recent years have witnessed the growth of 'crimmigration,' or the criminalization of immigration (Chacón 2012; Stumpf 2006), where immigration law is increasingly punitive and broad in scope (Ewing et al. 2015). Notably, while anxieties highlight "illegal" immigrants, concerns levied at the immigrant-crime nexus are more widely shared and felt by all immigrants (see Perea 1996; Rosaldo 1997).

The relation between illegal immigration and traditional criminal offending is a contested one. On the one hand, those who enter the country without authorization may comprise a select group of individuals whose criminal involvement prohibits them from legal entry or whose entrance to the country is for the purpose of engaging in crime. Similarly, if the revocation of one's legal status is the result of involvement with the criminal justice system, this may 


\section{Offending Histories of Undocumented Immigrants}

signal a heightened criminal propensity. ${ }^{2}$ Criminal behavior is a key determinant of revocation; an estimated seven and a half percent of undocumented immigrants have a criminal conviction, three-percent of whom have committed a felony offense (Rosenblum 2015). On the other hand, undocumented immigrants may be less criminally involved than their peers as they actively work to not draw attention to themselves and risk deportation (Gottfredson 2004). Belief in the obligation to obey the law among immigrants exceeds that of US-born peers (Correia 2010; Kirk et al. 2012; Piquero et al. 2014; Rengifo \& Fratello 2015) even among detained populations (Ryo 2017). In this vein, those who migrate to the US illegally are doing so, in large part, for economic opportunity, family reunification, and to flee violence (Chavez 2012; Massey et al. 2014).

Negligible empirical attention has been aimed at exploring differences in offending for immigrants distinguished by (un)documented status. Consequently, questions remain as to whether the lack of a relation between immigration and crime holds among the undocumented, and whether the undocumented population poses a unique criminal risk. The lack of research into the undocumented-immigrant-crime nexus is due, in large part, to the rarity in which datasets include information on offending and data on immigrants' documentation status. Official data sources that record details such as citizenship, legal and/or documented status are impacted by disparities in the criminal justice system that, all else equal, can result in disproportionately more severe outcomes for immigrants. For instance, immigrants are subject to heightened policing (Davies \& Fagan 2012), increased rates of pre-trial detention (Reid et al. 2005), and use of deportation in lieu of criminal proceedings (Hagan \& Palloni 1999). Notably, Orrick and colleagues find that nativity status (Orrick \& Piquero 2015) did not influence sentencing disparities and that deportation status (Orrick, Compofelice \& Piquero 2016) was associated with the receipt of shorter sentences. In short, it is unclear the extent to which disparities in criminal justice system contact may affect the validity of arrest and correctional data used to test for differences across subsamples.

The few empirical studies that distinguish immigrant status generally fail to find systematic evidence that undocumented immigrants pose a unique crime threat. Specifically, Katz and colleagues (2011) found that illegal immigrants (i.e., overstayed visa and undocumented entry) were less likely to use marijuana, methamphetamine, and illicit drugs compared to legal US citizens, but were more likely to report use of powder cocaine. In a series of studies, Hickman and colleagues compared recidivism rates among a sample of non-deportable

\footnotetext{
2 Unfortunately, though "overstayers" or those who arrive to the US legally and let their visa expire are the focus of heightened attention recently (see Passel \& Cohn 2016), too little is known about those with expired visas to speculate about whether these individuals would have heightened or lessened propensities to crime.
} 
(i.e., legal immigrants and naturalized U.S. citizens) and deportable immigrants (i.e., illegal entry, overstayed visa, or visa revocation) from the Los Angeles County jail. Hickman and Suttorp (2008) found that deportation status was not related to one-year reoffending risk, and overall re-arrest rates for the sample were relatively low $(38 \%)$ compared to recidivism rates within the general US prison population (Durose et al. 2014). More recently, Wong and colleagues (2015) and Hickman and colleagues (2016) found that authorization status did not predict re-arrest risk in a 9-year period following release; however a subsample of the unauthorized immigrant group (i.e. illegal entry, overstayed visa, or visa revocation), namely previously-deported immigrants, were at greater risk of recidivism than their peers.

\section{Current Research}

This study complements and advances limited existing research in a number of notable ways. First, we examine the offending behavior of undocumented and documented immigrants and compare their offending to similar justiceinvolved US-born peers. Second, drawing on a sample of youth selected into the study at their first arrest, with follow-up interviews occurring every 6 months for three years, the sample is comprised at baseline of individuals without prior formal justice system involvement that may systematically affect their offending. Moreover, the longitudinal nature of the data and the study's emphasis on the transition to adulthood allows us to examine changes in offending during peak years of risk for antisocial behavior. If differences in offending as a function of documentation status exist, it is reasonable to expect that these data would identify them. Finally, we examine both self-reported offending and official reports of (re)arrest to assess incidence (i.e., prevalence) and severity (i.e., variety/frequency) of offending.

\section{Method}

\section{Participants}

The sample comes from the Crossroads Study ${ }^{3}$ a prospective study of male, first-time juvenile offenders in three locales (Pennsylvania, Louisiana, and southern California). This study uses data from the southern California site ( $N$ $=532)$ because the vast majority of immigrant youth in the sample $(81 \%)$, and all of the undocumented immigrant youth, resided in that state. Crossroads is a longitudinal study designed to examine the effects of justice system involvement on first-time male juvenile offenders. Adolescent males who were first-time offenders (i.e., no prior arrests), were between the ages of 13 and 17 $\left(M_{\text {age }}=15.46, S D=1.21\right)$, and had committed an eligible offense (e.g.,

${ }^{3}$ For more information about the Crossroads Study, visit http://sites.uci.edu/crossroadsinfo/ 


\section{Offending Histories of Undocumented Immigrants}

vandalism, theft, assault) were eligible to participate in the Crossroads Study. The charges selected for study inclusion were moderate offenses that had similar probabilities of being diverted and formally processed in court, based on our review of historical records over the 5 -year period immediately prior to the commencement of the study. We identified eligible participants by monitoring all new arrest reports in one county in southern California. Approximately $80 \%$ of the eligible participants participated. The most frequent charge was vandalism $(47.10 \%)$ and $18.98 \%$ of the sample had been arrested for a person offense. Consistent with demographic characteristics of youth involved in the juvenile justice system in southern California, the analytic sample was: $80.71 \%$ Latino, $17.82 \%$ White, and $1.5 \%$ other. The preponderance of youth identified as being of Mexican ancestry: $95.7 \%$ of documented first-generation, $83.8 \%$ of undocumented first-generation, $85.7 \%$ of second-generation, and $85.7 \%$ of native-born Latinos (see Appendix for subsample descriptive statistics).

Youth with complete immigration data $(N=477)$ did not differ on any key study variable from the 532 youth enrolled in the CA site. Of the 477 youth who had complete immigration data, approximately $95.60 \%(N=456)$ had complete data on all official record and self-report study variables for all waves of the study. Results of Little's missing completely at random test indicated that data were missing completely at random (Li 2013; Little 1988; Little 1992).

\section{Procedures}

The Institutional Review Board (IRB) at University of California, Irvine approved the study procedures. Signed parental consent and youth assent were obtained for all participants before interviews were conducted. Participants were informed of the nature of the study and were told that there was no penalty for not participating. Youth completed an interview within 6 weeks after the disposition hearing for their first arrest, as well as follow-up interviews approximately $6,12,18,24,30$, and 36 months after their initial interview. Faceto-face interviews with the youth ranged from $2-3$ hours and were documented using a secure computer-administered program. A Privacy Certificate issued by the Department of Justice protects participants' privacy by exempting their identity and responses from subpoenas, court orders, or other types of involuntary disclosures. Participants were given a detailed explanation of the Privacy Certificate before beginning the interview and were reminded again before sensitive questions, such as those about offending and legal residency, were asked.

\section{Measures}

Immigration Status. Following convention in the literature (Pew Research Center 2013; Rumbaut \& Ewing 2007), immigrant status was determined using 
information on the country of birth of the youth and his parents as reported by the youth. Respondents born outside the US self-identified as legal resident (yes/no). First-generation immigrants include youth who have foreign-born parents and who were themselves born outside the US $N=60 ; 12.58 \%$ of the analytic sample). Of the first-generation immigrants, 37 reported that they were not "a legal resident of the United States" (7.76\%) and 23 as documented or holding legal residency $(4.82 \%)$. Second-generation immigrants include youth born in the US with at least one foreign-born parent $(N=266 ; 55.77 \%)$. Nativeborn White youth were born in the US to US-born parents and self-identified as White $(N=74 ; 15.51 \%)$. Native-born Latino youth were born in the US to US-born parents and self-identified as Hispanic/Latino $(N=77 ; 16.14 \%)$.

Self-reported Offending. Involvement in crime during each recall period was assessed using the Self-Report of Offending (SRO; Huizinga et al. 1991). Participants reported their history (lifetime and preceding six-months) of involvement in 24 criminal acts (ranging in severity from selling drugs to homicide). Two offending indices were created. First, a dichotomous indicator of offending $(1=$ yes) was created to capture prevalence. Second, responses were summed to indicate the number of different types of crimes in which the youth engaged. Variety scores are widely used in criminological research because they are highly correlated with measures of seriousness and frequency of antisocial behavior (see Monahan \& Piquero 2009), are less subject to recall bias than are frequency scores (see Hindelang et al. 1981; Osgood et al. 2002), and account for heterogeneity in crime types (Sweeten 2012).

Official Arrest. The southern California probation department and juvenile court provided access to official record arrest data. The official record data indicate both whether (prevalence) and the number of times (frequency) the youth had been re-arrested at each wave during the 36-months following his first arrest.

\section{Analytic Strategy}

We describe longitudinal patterns of the prevalence and variety of offending for five groups of youth: undocumented immigrant, documented immigrant, second-generation, US-born White, and US-born Latino. We provide the USborn youth as reference points and to situate this work in the empirical literature base. We first compare the prevalence and variety of offending leading up to and including study participants' adjudication arrest. We then examine patterns of offending using self-reported offending and officially recorded arrests for three years following baseline. Given the small sample sizes, we report the results of post hoc power analyses (Champely 2013; Faul et al., 2009), with power $(1-\beta)$ set at 0.80 and $\alpha=.05$, specifically to aid future research (see Hoenig \& Heisey 2001; Gilbert \& Prion 2016; Goodman \& Berlin 1994). We also include $95 \%$ confidence intervals for all effects. 


\section{Offending Histories of Undocumented Immigrants}

\section{Results}

\section{Offending Prior to First Arrest}

At their baseline interview, youth retrospectively self-reported both their total history of involvement in crime prior to their first arrest as well as their involvement in crime during the six months immediately prior to their first arrest. The pattern of results is similar across both measures of prior offending (i.e., ever versus 6 months). For instance, the results indicated that prior to baseline, self-reported offending was greatest for US-born youth and lowest for the foreign-born. Undocumented immigrants reported the lowest rates of offending compared to their peers (see Table 1). Self-reported offending among undocumented immigrant youth was significantly less than second-generation youth (incidence rate ratio $(I R R)^{4}=.71, S E=.11, p=.018,95 \% C I=.53, .94$; $1-\beta=.21)$ and US-born White youth $(\operatorname{IRR}=.75, S E=.13, p=.084,95 \% C I=$ $.54,1.04 ; 1-\beta=.17) .{ }^{5}$ Statistically significant differences in self-reported offending were not observed comparing undocumented immigrants with documented immigrants $(I R R=.92, S E=.21, p=.707,95 \% C I=.59,1.43 ; 1$ $\beta=.12)$ and US-born Latino youth $(I R R=.82, S E=.14, p=.234,95 \% C I=$ $.59,1.14 ; 1-\beta=.17)$.

\section{Arresting Offense}

We look next at the distribution of crimes for the arresting offense across subgroups. The majority of arrest offenses for all groups are for property crimes (see Table 1). Person-related crimes comprise roughly a quarter of arresting offenses for documented immigrants $(26.09 \%)$ and US-born Latino youth $(23.38 \%)$, with the lowest rates observed for undocumented immigrants (18.92\%), US-born Whites (17.57\%), and second-generation youth (15.41\%). Arresting offenses for drug related crimes are rare in this sample, comprising less than $5 \%$ for US-born Whites (4.1\%), US-born Latinos (1.3\%) and secondgeneration youth $(1.5 \%)$, and absent from documented and undocumented immigrant groups.

\section{Recidivism: Self-Reported Prevalence and Variety of Offending}

Cumulative prevalence rates for involvement in any crime across the three years are reported in Table 1. Following the first arrest, $65 \%$ of undocumented

\footnotetext{
${ }^{4}$ Incidence rate ratios (IRRs) are the ratio of the incidence rate in one group divided by the incidence rate of the comparison group. An IRR of 1 indicates that the outcome rate is equivalent between the groups, an IRR larger than 1 would indicate that the rate of reoffending among the target group is larger than the comparison group, and an IRR between 0 and 1 indicates that the rate of reoffending among that target group is smaller than the comparison group.

${ }^{5}$ The power analyses indicate that these effects were found even though the power to detect that effect was low for each analysis (.21 and .17, respectively). Because of the low power, it is critical that studies replicate these findings.
} 
immigrant youth self-report engaging in at least one crime, compared to $70 \%$ of documented immigrants, $77 \%$ of second-generation and US-born White, and $78 \%$ of US-born Latino youth in the sample. The cumulative re-arrest prevalence across the three-year period is statistically similar. Cumulatively across the three-year period, undocumented immigrant youth commit a smaller variety of crimes than second-generation $(I R R=.58, S E=.11, p=.003,95 \%$ $C I=.41, .83 ; 1-\beta=.21)$, US-born White (IRR $=.69, S E=.14, p=.067,95 \%$ $C I=.46,1.03 ; 1-\beta=.17)$, and US-born Latino $(I R R=.67, S E=.14, p=.054$, $95 \% C I=.45,1.01 ; 1-\beta=.17)$ youth.

Table 1. Prevalence of Self-Reported Offending and Officially Recorded ReArrest

\begin{tabular}{|c|c|c|c|c|c|c|}
\hline & $\begin{array}{l}\text { Full CA } \\
\text { Sample }\end{array}$ & $\begin{array}{c}\text { Documented } \\
\text { First } \\
\text { Generation }\end{array}$ & $\begin{array}{c}\text { Undocumented } \\
\text { First } \\
\text { Generation } \\
\end{array}$ & $\begin{array}{l}\text { Second } \\
\text { Generat } \\
\text { ion }\end{array}$ & $\begin{array}{l}\text { Native- } \\
\text { born } \\
\text { White }\end{array}$ & $\begin{array}{l}\text { Native- } \\
\text { born } \\
\text { Latino }\end{array}$ \\
\hline $\mathrm{N}$ & $\begin{array}{l}N= \\
477\end{array}$ & $N=23$ & $N=37$ & $\begin{array}{l}N= \\
266\end{array}$ & $\mathrm{~N}=74$ & $\mathrm{~N}=77$ \\
\hline$\%$ of Sample & 100 & 5 & 8 & 56 & 16 & 16 \\
\hline \multicolumn{7}{|l|}{$\begin{array}{l}\text { Pre-Baseline Self- } \\
\text { Reported Offending }\end{array}$} \\
\hline $\begin{array}{l}\text { Total Variety Ever } \\
M(S D)\end{array}$ & $\begin{array}{c}3.77 \\
(3.24) \\
\end{array}$ & $\begin{array}{c}3.09 \\
(1.81)\end{array}$ & $\begin{array}{c}2.84 \\
(2.60) \\
\end{array}$ & $\begin{array}{c}4.03 \\
(3.38) \\
\end{array}$ & $\begin{array}{c}3.80 \\
(2.94)\end{array}$ & $\begin{array}{c}3.47 \\
(3.53)\end{array}$ \\
\hline \multicolumn{7}{|l|}{ Arresting Offense } \\
\hline Drug (\%) & 1.68 & 0 & 0 & 1.5 & 4.05 & 1.30 \\
\hline Person (\%) & 16.56 & 21.74 & 13.51 & 15.04 & 14.86 & 23.38 \\
\hline Property $(\%)$ & 72.96 & 69.57 & 75.68 & 73.31 & 71.62 & 72.73 \\
\hline Other $(\%)$ & 8.81 & 8.70 & 10.81 & 10.15 & 9.46 & 2.60 \\
\hline \multicolumn{7}{|l|}{$\begin{array}{l}\text { Cumulative Self- } \\
\text { Reported Offending } \\
\text { Across } 3 \text { Years }\end{array}$} \\
\hline Prevalence Total (\%) & 75.58 & 69.57 & 64.86 & 76.69 & 76.39 & 77.92 \\
\hline Variety $M(\mathrm{SD})$ & $\begin{array}{c}4.23 \\
(4.21) \\
\end{array}$ & $\begin{array}{c}3.13 \\
(3.28)\end{array}$ & $\begin{array}{l}2.70 \\
(2.37)\end{array}$ & $\begin{array}{c}4.68 \\
(4.53)\end{array}$ & $\begin{array}{c}3.95 \\
(3.76)\end{array}$ & $\begin{array}{c}4.01 \\
(4.18)\end{array}$ \\
\hline \multicolumn{7}{|l|}{$\begin{array}{l}\text { Cumulative Re-arrests } \\
\text { across } 3 \text { Years }\end{array}$} \\
\hline $\begin{array}{l}\text { Prevalence of re-arrest } \\
(\%)\end{array}$ & 44.86 & 39.13 & 48.65 & 46.99 & 39.19 & 42.86 \\
\hline $\begin{array}{l}\text { Frequency re-arrests } \\
M(S D)\end{array}$ & $\begin{array}{l}1.23 \\
(1.99)\end{array}$ & $\begin{array}{l}.57 \\
(.84)\end{array}$ & $\begin{array}{l}1.54 \\
(2.22)\end{array}$ & $\begin{array}{l}1.35 \\
(2.11)\end{array}$ & $\begin{array}{c}.97 \\
(1.82)\end{array}$ & $\begin{array}{c}1.10 \\
(1.83)\end{array}$ \\
\hline
\end{tabular}

The wave-specific average rate of self-reported offending prevalence and offending variety across immigrant and US-born subsamples are reported in Figure 1. Following the baseline arrest, all study youth evidence a decline in the prevalence and variety of offending across the three-year study period. While there is variation in the relative rank ordering of the immigrant and US-born subsamples at each follow-up, undocumented first-generation immigrants consistently report the lowest prevalence of offending and the lowest variety of offending compared to their documented immigrant and US-born peers. 


\section{Offending Histories of Undocumented Immigrants}

We report the statistical differences in offending prevalence and variety at each follow-up wave; however, we again note that fluctuations in statistical significance may be influenced by the sample sizes. Because our interest is in examining involvement in crime among undocumented immigrants, we use this group as the statistical comparison. Overall, when significant differences are observed, they are in the direction of undocumented immigrants offending at lower rates than their US-born peers. ${ }^{6}$ Regarding differences in the variety of offending, the patterns suggest that undocumented immigrants are involved in a smaller variety of offenses than native-born Latino or White youth at certain waves, but not consistently throughout the three years. Undocumented immigrants consistently committed a smaller variety of offenses than secondgeneration youth. ${ }^{7}$

\section{Recidivism: Officially Recorded Re-arrest}

In contrast to the findings for the self-reported offending measures, relative to their peers, undocumented immigrants are re-arrested at a higher rate and more often in the three-years following their first arrest. The cumulative prevalence of re-arrest for all groups falls between $40 \%$ and $50 \%$ (see Table 1). Nearly half of undocumented immigrants reported a subsequent arrest, and of those rearrested, the average rate of re-arrest is 1.54 . The lowest rates of re-arrest are observed for documented immigrant $(39.13 \%$; mean number of re-arrests $=$ $.57)$ and US-born White $(39.19 \%$; mean number of re-arrests $=.97)$ youth. Although undocumented immigrant youth are just as likely to be re-arrested as documented immigrant youth $(O R=1.47, S E=.80, p=.472,95 \% C I=.51$, $4.24 ; 1-\beta=.16)$ and their US-born White peers $(O R=1.47, S E=.60, p=.343$, $95 \% C I=.66,3.26 ; 1-\beta=.21)$, undocumented immigrants are re-arrested more

\footnotetext{
${ }^{6}$ At six months following the first arrest, undocumented first-generation youth reoffended significantly less than US-born Latino youth (Odds ratio $(O R)=.47, S E=.19, p=.064,95 \% C I=.21,1.04 ; 1-\beta=.72$ ). At 12 and 18 months, undocumented first-generation youth did not differ from other groups of youth. By 24 months, undocumented first-generation youth reoffended less than the native-born White youth $(\mathrm{OR}=$ $.44, S E=.19, p=.058,95 \% C I=.19,1.03 ; 1-\beta=.43)$. At 30 months, there were no differences in reoffending rates. Finally, at 36 months, undocumented first-generation youth reoffended significantly less than the native-born White youth $(O R=.41, S E=.19, p=.051,95 \% C I=.16,1.01 ; 1-\beta=.47)$ and less than native-born Latino youth $(O R=.46, S E=.21, p=.091,95 \% C I=.19,1.13 ; 1-\beta=.41)$.

${ }^{7}$ Undocumented first-generation youth committed a smaller variety of offenses than US-born White youth at 12 months $(I R R=.46, S E=.18, p=.050,95 \% C I=.22, .99$; Cohen's $d=.41 ; 1-\beta=.17)$.

Undocumented first-generation youth also committed a smaller variety of offenses than US-born Latino youth at both 18 months $(I R R=.41, S E=.16, p=.025,95 \% C I=.18, .89$; Cohen's $d=.41 ; 1-\beta=.17)$ and 24 months $(I R R=.47, S E=.20, p=.072,95 \% C I=.21,1.07$; Cohen's $d=.32 ; 1-\beta=.17)$. Finally, undocumented first-generation youth committed a smaller variety of offenses than second-generation youth at six months $(I R R=.60, S E=.17, p=.076,95 \% C I=.35,1.05$; Cohen's $d=.30 ; 1-\beta=.21), 12$ months $(I R R=.42, S E=.15, p=.013,95 \% C I=.21, .83$; Cohen's $d=.45 ; 1-\beta=.21), 18$ months $(I R R=$ $.40, S E=.15, p=.012,95 \% C I=.20, .82$; Cohen's $d=.41 ; 1-\beta=.21), 24$ months $(I R R=.47, S E=.18, p$ $=.043,95 \% C I=.23, .98$; Cohen's $d=.34 ; 1-\beta=.21)$, and 36 months $(\operatorname{IRR}=.42, S E=.17, p=.031,95 \%$ $C I=.19, .93$; Cohen's $d=.35 ; 1-\beta=.21$ ).
} 
Figure 1. Average Rate of Self-Reported Offending by Immigrant and Native-born Status

A. Total Crime Offending Prevalence

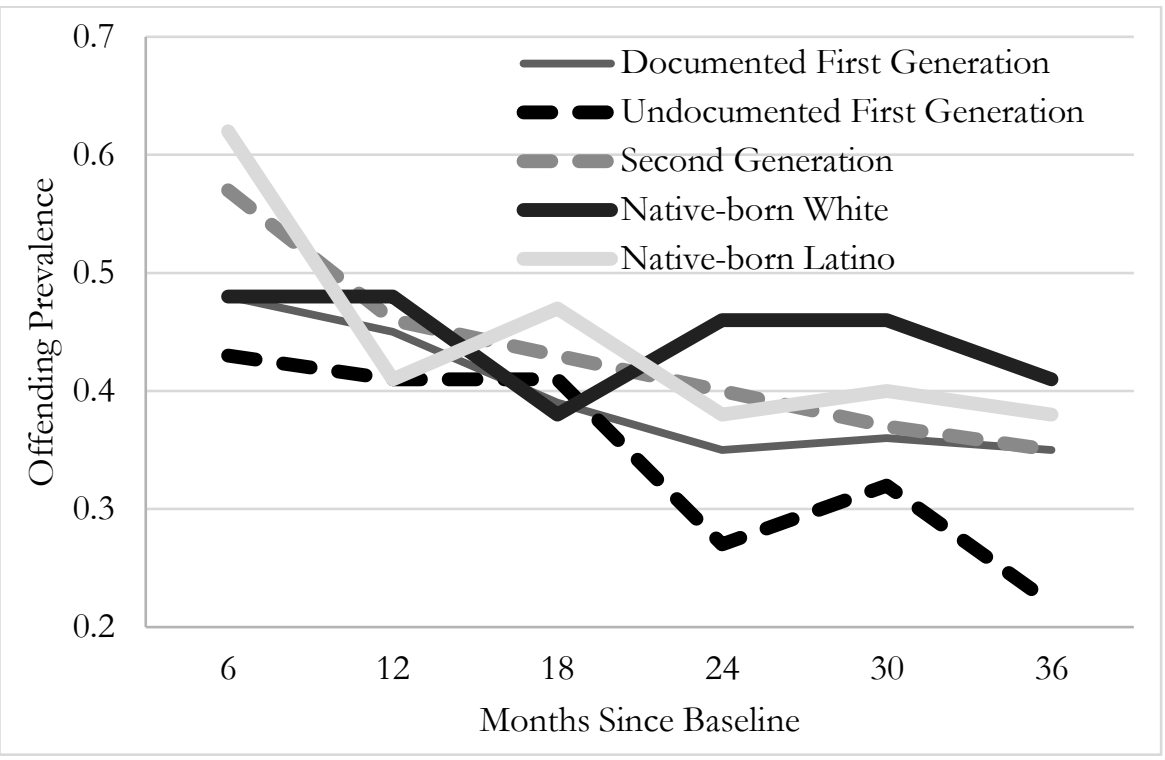

B. Total Crime Offending Variety

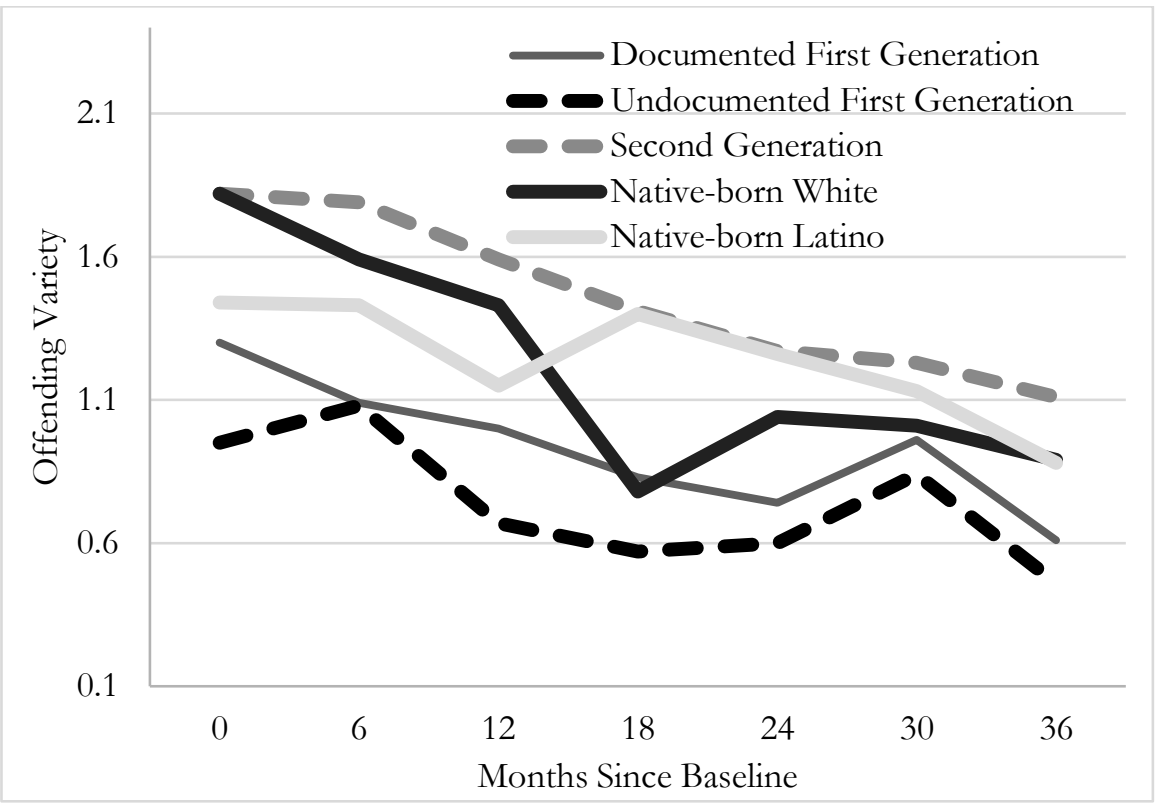




\section{Offending Histories of Undocumented Immigrants}

Figure 2. Average Rate of Re-Arrest by Immigrant and Native-born Status

A. Re-arrest Prevalence

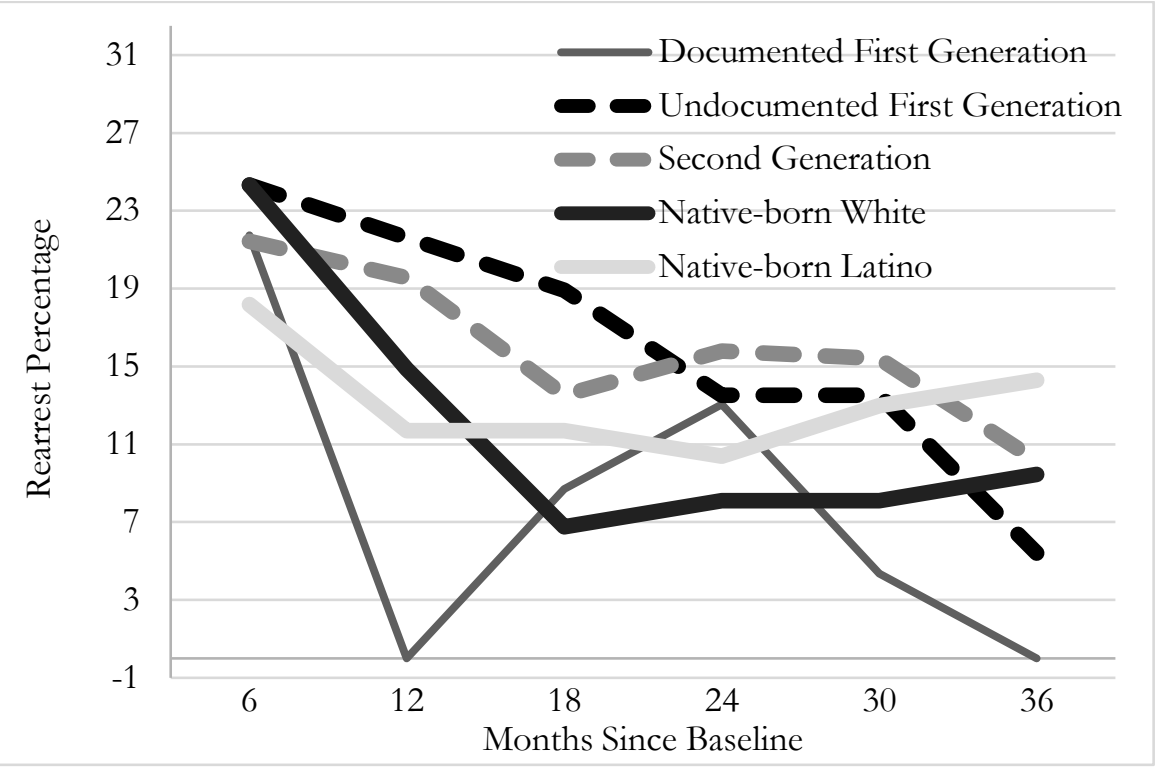

B. Re-arrest Means

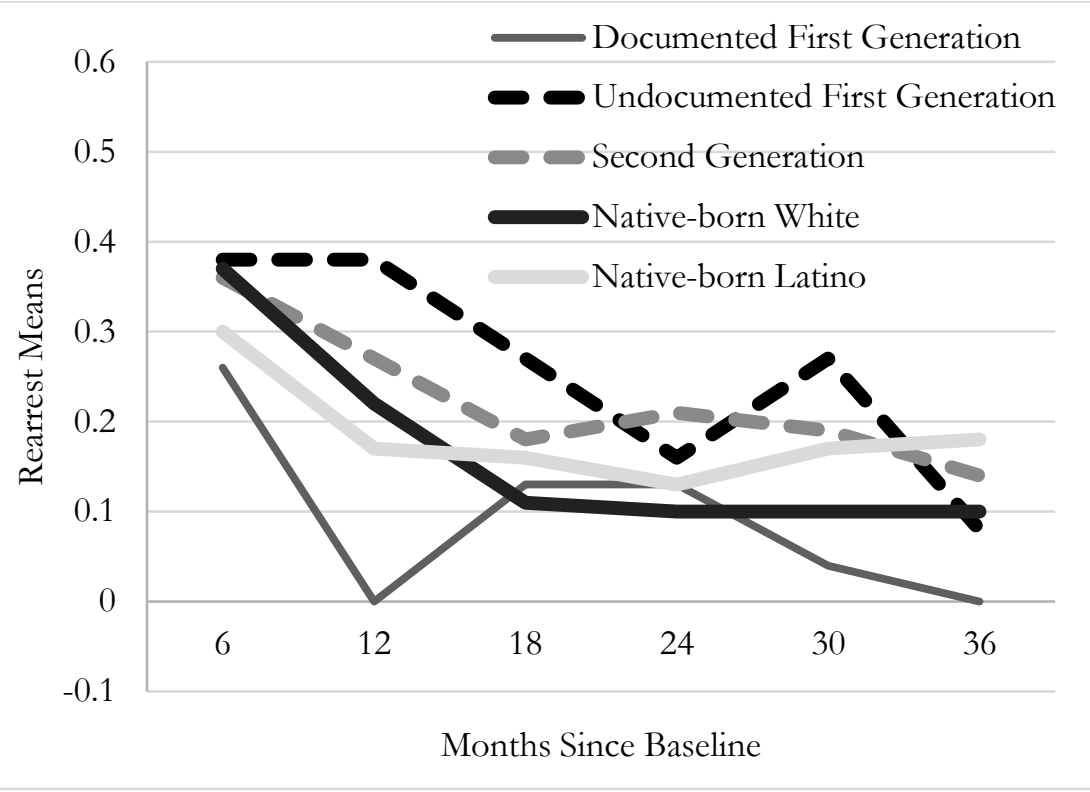


frequently than documented immigrant youth $(\operatorname{IRR}=2.73, S E=1.33, p=.041$, 95\% $C I=1.05,7.11 ; 1-\beta=.53)$.

We examine wave-specific rates of re-arrest prevalence and frequency (see Figure 2). Following the baseline arrest, all study youth evidence a general decline in the prevalence and frequency of re-arrest across the three-years. While there is variation in the relative rank ordering at each follow-up, undocumented immigrants are generally re-arrested more frequently than are their documented first-generation immigrant and US-born peers (results available upon request).

\section{Robustness Analyses}

We assess the robustness of our findings in two ways. First, because the majority of immigrants in the full three-site Crossroads sample reside in California, the analyses thus far have focused on youth in California. As a robustness check, we replicated all analyses using data from all three study sites. The model results were largely consistent. One exception is that analyses conducted using data from all three sites suggests that undocumented immigrants engaged in less self-reported offending prior to baseline than documented immigrants $(I R R=.73, S E=.11, p=.043,95 \% C I=.54, .99)$.

Second, because of the longitudinal nature of the data and the clustering of observations within individuals, we conducted a series of multi-level models (MLM; Fitzmaurice et al. 2012; Lui et al. 2012; Singer \& Willett 2004) and examined whether immigration status accounts for variability in self-reported offending and re-arrest over time (all results available upon request). MLMs conceptualize growth curves using several levels of analysis, with time/observations as level 1 and individuals as level 2. We estimated growth models accounting for age (centered on 13) and traditional correlates of offending (i.e., socioeconomic status, parental criminality) ${ }^{8}$ While we present these findings cautiously given the small sample sizes and large standard errors, considering the correlations among repeated observations provides a more precise estimate of the rate of change and have more power as compared with traditional models (Fitzmaurice et al. 2012). The results from the MLM analysis confirm those reported above: 1) re-offending rates are generally lowest for undocumented immigrants, and 2) undocumented immigrants tend to be rearrested more frequently, particularly in the first year following their initial arrest.

\footnotetext{
${ }^{8}$ Parent highest level of education is used as a proxy for socioeconomic status. Based on the distribution, the variable was split into three categories for analyses: $40.9 \%$ had parents who had not finished high school, 23.5\% had parents who had finished high school or had received a GED, and 35.6\% had at least some exposure to higher education (e.g., trade, business, professional, or college). Parental criminality measures the history of arrest for either parent. Across the sample, approximately $14.46 \%$ of the sample had at least one parent who had been arrested.
} 


\section{Offending Histories of Undocumented Immigrants}

\section{Discussion}

The American public consistently worries about illegal immigration, with nearly half perceiving that immigrants make American society worse when it comes to crime (Lopez, Passel and Rohal 2015). Yet, mounting empirical evidence finds immigrants are less likely to commit crime than their US-born peers. The research-rhetoric disconnect is due, at least in part, to the limited data and analysis distinguishing undocumented immigrants. To our knowledge, this is the first study to examine longitudinal patterns of youthful offending using selfreport and officially-recorded arrests distinguishing immigrants by their legal residency status.

First, consistent with previous research, self-reported offending prior to engagement with the justice system (i.e., first arrest) is relatively and consistently low for immigrants generally and for undocumented immigrants specifically compared to their US-born peers. Second, compared to their documented immigrant and US-born peers, undocumented immigrants continue to report low levels of offending in the three-years following first arrest. Third, and in contrast to the findings for self-reported offending, undocumented immigrants are more likely to be re-arrested and are re-arrested more in the three-years following their first arrest. Differences in the risk of re-arrest appear to be most pronounced immediately following their first arrest.

The divergent finding using the self-reported offending and officially recorded arrest outcomes warrants further scrutiny. While it may be the case that this divergence reflects systematic crime reporting bias, research by Bersani and Piquero (2017) finds no evidence that immigrants accused of serious crimes under-report their offending and may instead over-report crime compared to their US-born peers. First arrest may trigger increased scrutiny and reduced tolerance for deviance that increases the risk for secondary sanctioning (see Doherty et al. 2016; Liberman et al. 2014; Morris \& Piquero 2013), which may be amplified for the undocumented. Analyses are needed to disentangle whether the pattern of results observed here reflect differential treatment in the process of the administration of the law, differential involvement in crime, or some combination of the two (Piquero 2008).

Collectively, research on immigration and crime suggests that undocumented immigration status does not distinguish a group of distinctly crime-prone individuals. The current study represents a next step in the ever-developing research base on the immigrant-crime nexus. It is critical to note, however, that the sample sizes for the foreign-born group are small, particularly when disaggregated by legal residency status. Although this is a clear limitation, longitudinal data containing information on self-reported and official measures of crime as well as immigrant (un)documented status are exceptionally rare. Though the data demands are high and studies of youthful populations are 
difficult to conduct, researchers should replicate these analyses as data become available. This research is also limited to examining offending among Latino youth. Research is needed to replicate this study with larger, more diverse samples.

\section{Conclusion}

Justification for heightened immigration enforcement and the criminalization of immigration law is based on the assertion that undocumented immigrants represent a distinctly dangerous class. With this research, we add to the limited knowledge base and investigate crime among those lacking legal US residency by assessing patterns of offending longitudinally, both prior to and following first arrest, using self-reported offending and officially recorded arrest measures. The nature of the sample allows for a thorough study of offending patterns during precisely the developmental period when criminal involvement is at its peak. Nonetheless, results show that undocumented immigrants generally report the lowest rate of offending prior to and following their first arrest. Yet despite offending less, undocumented immigrants are more likely to be re-arrested in the three-years following their initial contact with the justice system. Divergence in the pattern of results contingent upon the measure of criminal behavior - self-report or official arrest - warrants focused consideration to disentangle whether the difference is due to: systematic crime reporting bias (e.g., under-reporting of crime among undocumented immigrants), differential treatment in the criminal justice system (e.g., intensified policing), or a combination of factors.

\section{References}

Bersani, Bianca E. 2014. An Examination of First and Second Generation Immigrant Offending Trajectories. Justice Quarterly 31:315-343.

Bersani, Bianca E., Thomas A. Loughran, and Alex R. Piquero. 2014. Comparing Patterns and Predictors of Immigrant Offending Among a Sample of Adjudicated Youth. Journal of Youth and Adolescence 43:1914-1933.

Bersani, Bianca E. and Alex R. Piquero. 2017. Examining Systematic Crime Reporting 31 Bias Across Three Immigrant Generations: Prevalence, Trends and Divergence in 32 Self-Reported and Official Reported Arrests. Journal of Quantitative Criminology, 33(4): 835-857.

Bui, Hoan N. 2009. Parent-Child Conflicts, School Troubles, and Differences in Delinquency across Immigrant Generations. Crime \& Delinquency 55:412-441.

Butcher, Kristin F. and Anne Morrison Piehl. 1998. Cross-City Evidence on the Relationship between Immigration and Crime. Journal of Policy Analysis and Management 17:457-493.

Chacón, Jennifer M. 2012. Overcriminalizing Immigration. Journal of Criminal Law and Criminology 102: 613-652. 


\section{Offending Histories of Undocumented Immigrants}

Champely, Stephane. 2013. Package 'pwr'. Available from http://cran.rproject.org/web/pack ages/pwr/pwr.pdf. Last accessed: May 6, 2017.

Chavez, Leo R. 2012. Shadowed lives: Undocumented immigrants in American society. Cengage Learning.

Chaves, Leo R. 2008. The Latino Threat: Constructing Immigrants, Citizens, and the Nation. Stanford: Stanford University Press.

Correia, Mark E. 2010. Determinants of Attitudes toward Police of Latino Immigrants and Non-Immigrants. Journal of Criminal Justice 38:99-107.

Davies, Garth and Jeffrey Fagan. 2012. Crime and Enforcement in Immigrant Neighborhoods: Evidence from New York City. The ANNALS of the American Academy of Political and Social Science 641:99-124.

Doherty, Elaine Eggleston, Jaclyn M. Cwick, Kerry M. Green, and Margaret E. Ensminger. 2016. Examining the consequences of the "prevalent life events" of arrest and incarceration among an urban African-American cohort. Justice Quarterly 33: 970-999.

Durose, Matthew R., Alexia D. Cooper and Howard N. Snyder. 2014. Recidivism of Prisoners Released in 30 States in 2005: Patterns from 2005-2010. Washington, DC: US Department of Justice.

Ewing, Walter. A., Daniel E. Martínez, and Rubén G. Rumbaut. 2015. The Criminalization of Immigration in the United States. Washington, DC: American Immigration Council Special Report.

Fitzmaurice, Garrett, M., Nan M. Laird, \& James H Ware. 2012. Applied longitudinal analysis (Vol. 998). John Wiley \& Sons.

Faul, Franz, Edgar Erdfelder, Axel Buchner, and Albergt-Georg Lang. 2009. Statistical power analyses using $G^{*}$ Power 3.1: Tests for correlation and regression analyses. Behavior Research Methods, 41, 1149-1160.

Gilbert, Gregory, E., and Susan Prion. 2016. Making Sense of Methods and Measurement: The Danger of the Retrospective Power Analysis. Clinical Simulation in Nursing 12.8: 303-304.

Gonzales, Roberto G. 2016. Lives in Limbo: Undocumented Coming of Age in America. Oakland, CA: California University Press.

Goodman, Steven, and Jesse Berlin. 1994. The use of predicted confidence intervals when planning experiments and the misuse of power when interpreting results. Annals of internal medicine 121.33: 200-206.

Gottfredson, Michael R. 2004. Crime, Immigration, and Public Policy. Report prepared for the Merage Foundation for the American Dream.

Hagan, John and Alberto Palloni. 1999. Sociological Criminology and the Mythology of Hispanic Immigration and Crime. Social Problems 46:617-632.

Harris, Kathleen Mullan. 1999. The Health Status and Risk Behaviors of Adolescents in Immigrant Families. In Children of Immigrants: Health, Adjustment, and Public Assistance, D. J. Hernandez (ed.), Pp. 286-347. Washington, DC: National Academy Press.

Hickman, Laura J., and Marika J. Suttorp. 2008. Are deportable aliens a unique threat to public safety? Comparing the recidivism of deportable and nondeportable aliens. Criminology and Public Policy 7:59-82.

Hickman, Laura J., Jennifer Wong and Marika Suttorp-Booth. 2016. Is Previous Removal From the United States a Marker for High Recidivism Risk? Results from 
a 9-Year Follow-Up Study of Criminally Involved Unauthorized Immigrants. Criminal Justice Policy Review 27:378-401.

Hindelang, Michael J., Travis Hirschi, and Joseph G. Weis. 1981. Measuring delinquency. Beverly Hills: Sage Publications.

Hirschi, Travis, and Michael Gottfredson. 1983. Age and the Explanation of Crime. American Journal of Sociology 89.3: 552-584.

Hoenig, John M. and Heisey, Dennis M. 2001. The Abuse of Power: The Pervasive Fallacy of Power Calculations for Data Analysis. The American Statistician 55.1: 1-6.

Huizinga, David, Finn-Age Esbensen, and Anne Wylie Weiher. 1991. Are there multiple paths to delinquency? Journal of Criminal Law and Criminology, 82, 83-118.

Ibañez, Gladys E., Michelle Agudo, Steve S. Martin, Daniel J. O’Connell, Rehab Auf, and Diana M. Sheehan. 2017. Offending Behavior, Drug Use, and Mental Health Among Foreign-Born versus US-Born Latino Criminal Justice Clients. Journal of Immigrant and Minority Health, 19(3): 674-685.

Jennings, Wesley G., Kristen M. Zgoba, Alex R. Piquero, and Jennifer M. Reingle. 2013. Offending Trajectories among Native-Born and Foreign-Born Hispanics to Late Middle Age. Sociological Inquiry 83:622-647.

Katz, Charles M., Andrew M. Fox, and Michael D. White. 2011. Assessing the Relationship between Immigration Status and Drug Use. Justice Quarterly 28:541575.

Kirk, David S., Andrew V. Papachristos, Jeffrey Fagan, and Tom R. Tyler. 2012. The Paradox of Law Enforcement in Immigrant Communities: Does Tough Immigration Enforcement Undermine Public Safety? The ANNALS of the American Academy of Political and Social Science 641:79-98.

Lee, Matthew T. and Ramiro Martinez, Jr. 2009. Immigration Reduces Crime: An Emerging Scholarly Consensus. In Immigration, Crime and Justice., vol. 13, Sociology of Crime, Law and Deviance, W. F. Mcdonald (ed.), Pp. 3-16. Bingley, UK: Emerald Group Publishing Limited.

Li, Cheng. 2013. Little's Test of Missing Completely at Random. The Stata Journal, 795.

Liberman, Akiva M., David S. Kirk, and Kideuk Kim. 2014. Labeling effects of first juvenile arrests: Secondary deviance and secondary sanctioning. Criminology 52: 345370.

Lui, Siwei, Michael J. Rovine and Peter Molenaar. 2012. Selecting a Linear Mixed Model for Longitudinal Data: Repeated Measures Analysis of Variance, Covariance Pattern Model, and Growth Curve Approaches. Psychological Methods 17:15-30.

Little, Roderick JA. 1988. Missing-data Adjustments in Large Surveys. Journal of Business and Economic Statistics 6:287-296.

Little, Roderick JA. 1992. Regression with Missing X's: A Review. Journal of the American Statistical Association 87:1227-1237.

Lopes, Mark Hugo, Jeffrey Passel, and Molly Rohal. 2015. Modern Immigration Wave Brings 59 Million to U.S., Driving Population Growth and Change Through 2065: Views of Immigration's Impact on U.S. Society Mixed. Washington, DC: Pew Research Center.

Massey, Douglas S., Jorge Durand, and Karen A. Pren. 2014. Explaining Undocumented Migration to the US. International Migration Review 48.4:1028-1061.

Meissner, Doris, Donald M. Kerwin, Muzaffar Chishti, and Claire Bergeron. 2013. Immigration Enforcement in the United States: The Rise of a Formidable Machinery. Washington, DC: Migration Policy Institute. 


\section{Offending Histories of Undocumented Immigrants}

Monahan, Kathryn C. and Alex R. Piquero. 2009. Investigating the Longitudinal Relation between Offending Frequency and Offending Variety. Criminal Justice and Behavior 36:653-673.

Monahan, Kathryn C., Laurence Steinberg and Alex R. Piquero. 2015. Juvenile Justice Policy and Practice: A Developmental Perspective. In M. Tonry (Ed.), Crime and Justice: A Review of Research (vol. 44, pp. 577-619). Chicago: University of Chicago Press.

Morris, Robert G., and Alex R. Piquero. 2013. For whom do sanctions deter and label?. Justice Quarterly 30: 837-868.

Orrick, Erin A., and Alex R. Piquero. 2015. Assessing the impact of Mexican nativity on sentence length. Criminal Justice Policy Review 26:643-664.

Orrick, Erin A., Kiersten Compofelice, and Alex R. Piquero. 2016. Assessing the Impact of Deportable Status on Sentencing Outcomes in a Sample of State Prisoners. Journal of Crime and Justice 39: 28-40.

Osgood, D. Wayne, Barbara J. McMorris, and Maria T. Potenza. 2002. Analyzing Multiple-item Measures of Crime and Deviance I: Item Response Theory Scaling. Journal of Quantitative Criminology 18:267-296.

Passel, Jeffrey S. and D'Vera Cohn. 2016. Overall Number of U.S. Unauthorized Immigrants Holds Steady Since 2009. Pew Research Center. Washington, DC.

Passel, Jeffrey S. and D’Vera Cohn. 2016. Homeland Security Produces First Estimate of Foreign Visitors to U.S. who Overstay Deadline to Leave. Pew Research Center. Washington, DC.

Perea, Juan F. 1996. Introduction. Pp. 1-10 in Immigrants Out! The New Nativism and the Anti-Immigrant Impulse in the United States, edited by J. F. Perea. New York, NY: New York University Press.

Pew Research Center. 2013. Second-generation Americans: A portrait of the adult children of immigrants. Washington, DC: Pew Research Center.

Piquero, Alex R. 2008. Disproportionate Minority Confinement. The Future of Children 18:59-79.

Piquero, Alex R., Bianca E. Bersani, Thomas A. Loughran and Jeffrey Fagan. 2014. Longitudinal Patterns of Legal Socialization in First-Generation Immigrants, Second-Generation Immigrants, and Native-Born Serious Youthful Offenders. Crime \& Delinquency 62:1403-1425.

Piquero, Alex R., David P. Farrington and Alfred Blumstein. 2003. The Criminal Career Paradigm: Background and Recent Developments. In M. Tonry (Ed.), Crime and Justice: A Review of Research (vol. 30, pp. 359-506). Chicago: University of Chicago Press.

Portes, Alejandro and Rubén G. Rumbaut. 2006. Immigrant America: A Portrait (3 ${ }^{\text {rd }}$ edition). Berkeley, CA: University of California Press.

Reid, Lesley Williams, Harald E. Weiss, Robert M. Adelman, and Charles Jaret. 2005. The immigration-crime relationship: Evidence across US metropolitan areas. Social Science Research 34: 757-780.

Rengifo, Andres F., and Jennifer Fratello. 2014. Perceptions of the Police by Immigrant Youth: Looking at Stop-and-Frisk and Beyond Using a New York City Sample. Youth Violence and Juvenile Justice 1-19.

Rosenblum, Marc R. 2015. Understanding the Potential Impact of Executive Action on Immigration Enforcement. Washington, DC: Migration Policy Institute 
Rosaldo, Renato. 1997. Cultural Citizenship, Inequality, and Multiculturalism. In Latino Cultural Citizenship: Claiming Identity, Space, and Rights: 27-38.

Rumbaut, Ruben G., and Walter A. Ewing. 2007. The myth of immigrant criminality and the paradox of assimilation: Incarceration rates among native and foreign-born men. Washington, DC: Immigration Policy Center.

Ryo, Emily. 2017. Legal Attitudes of Immigrant Detainees. Law \& Society Review 51:99_ 131.

Simes, Jessica T. and Waters, Mary C. 2014. The Politics of Immigration and Crime, pp. 457-483 in Sandra M. Bucerius and Michael Tonry, eds., The Oxford Handbook of Ethnicity, Crime, and Immigration. New York, NY: Oxford University Press.

Stumpf, Juliet. 2006. The Crimmigration Crisis: Immigrants, Crime, and Sovereign Power. American University Law Review 56:367-419.

Sweeten, Gary. 2012. Scaling Criminal Offending. Journal of Quantitative Criminology 28:533-557.

Telles, Edward E., and Vilma Ortiz. 2008. Generations of Exclusion: Mexican Americans, Assimilation, and Race. New York: Russell Sage Foundation.

Vaughn, Michael G., Christopher P. Salas-Wright, Matt DeLisi, and Brandy R. Maynard. 2014. The Immigrant Paradox: Immigrants are Less Antisocial than Native-Born Americans. Social Psychiatry and Psychiatric Epidemiology 49:1129-1137.

Wang, Xia. 2012. Undocumented Immigrants as Perceived Criminal Threat: A Test of the Minority Threat Perspective. Criminology 50:743-776.

Wong, Jennifer S., Laura J. Hickman, and Marika Suttorp-Booth. 2015. Examining Recidivism among Foreign-born Jail Inmates: Does Immigration Status Make a Difference over the Long Term? Global Crime 16:265-287. 
166 Offending Histories of Undocumented Immigrants

\section{Appendix. Sample Descriptive Statistics}

\begin{tabular}{|c|c|c|c|c|c|c|}
\hline & 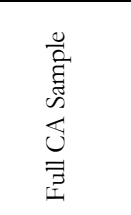 &  & 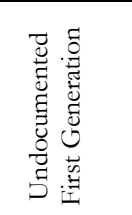 & 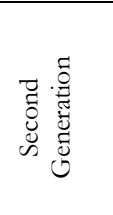 & 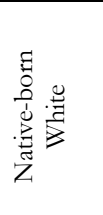 & 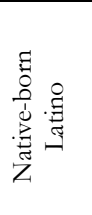 \\
\hline $\mathrm{N}$ & $N=477$ & $N=23$ & $N=37$ & $N=266$ & $\mathrm{~N}=74$ & $\mathrm{~N}=77$ \\
\hline$\%$ of Sample & 100 & 5 & 8 & 56 & 16 & 16 \\
\hline $\begin{array}{l}\text { Age at baseline } \\
M(S D)\end{array}$ & $\begin{array}{l}15.46 \\
(1.20)\end{array}$ & $\begin{array}{l}15.35 \\
(1.30)\end{array}$ & $\begin{array}{l}15.22 \\
(1.18)\end{array}$ & $\begin{array}{l}15.48 \\
(1.20)\end{array}$ & $\begin{array}{l}15.69 \\
(1.10)\end{array}$ & $\begin{array}{l}15.34 \\
(1.31)\end{array}$ \\
\hline Latino (\%) & 80.71 & 100 & 100 & 93.23 & 0 & 100 \\
\hline $\begin{array}{l}\text { Age at migration } \\
M_{\text {years }}(S D)\end{array}$ & $0.67(2.06)$ & $4.83(3.11)$ & $5.13(3.09)$ & --- & --- & --- \\
\hline \multicolumn{7}{|l|}{$\begin{array}{l}\text { Parental } \\
\text { Education (\%) }\end{array}$} \\
\hline $\begin{array}{l}\text { No High } \\
\text { School Diploma }\end{array}$ & 40.88 & 40.91 & 65.71 & 55.24 & 1.35 & 21.06 \\
\hline $\begin{array}{l}\text { High School } \\
\text { Diploma }\end{array}$ & 23.52 & 27.27 & 25.71 & 22.18 & 21.62 & 27.63 \\
\hline $\begin{array}{l}\text { More than } \\
\text { High School }\end{array}$ & 35.6 & 31.82 & 8.57 & 22.58 & 77.03 & 51.32 \\
\hline $\begin{array}{l}\text { Parental Arrest } \\
(\%)\end{array}$ & 14.46 & 0.00 & 8.10 & 15.04 & 16.21 & 18.18 \\
\hline
\end{tabular}

